\title{
Frequently Used Herbal Teas During Pregnancy - Short Update
}

\author{
Gebelikte Sıklıkla Kullanılan Bitkisel Çaylar - Kısa Derleme
}

\section{Berna TERZIOGLU BEBITOGLU ๑}

Ethics Committee Approval: Not Applicable.

Conflict of interest: The author has declared that she has no conflict of interest. Funding: None.

Informed Consent: Not Applicable.
Cite as: Terzioglu Bebitoglu B. Frequently used herbal teas during pregnancy - Short update. Medeniyet Med J. 2020;35:55-61.

\begin{abstract}
The prevalence of herbal medicine use during pregnancy varies depending upon the geographical location and socio-cultural factors. With the belief of "being natural is safe", use of herbs and herbal products has become popular worldwide and used more frequently including period of pregnancy. The potential unwanted effects of any substance is more important during pregnancy period, because cellular development and division of the rapidly growing fetus is vulnerable to these adverse effects. As with medicines, herbal products must at least interact with a component of the organism at the molecular level in order to exert a response. Herbal preparations most commonly used during pregnancy were teas or infusions (hot-water extracts of dried herbs) which usually have the lowest concentrations and contain the least amount of compounds. The purpose of this review is to summarize the herbs that are most commonly used as "herbal teas" during pregnancy and their potential toxic effects to highlight the importance of being cautious about their use.
\end{abstract}

Keywords: Herbal product, herbal tea, pregnancy

öz

Hamilelikte bitkisel ürün kullanımın prevalansı coğrafya ve sosyo-kültürel faktörlere bağlı olarak, değișmektedir. "Doğal olan güvenlidir" inancılla, bitkiler ve bitkisel ürünlerinin kullanımı dünya genelinde popüler hale gelmiştir ve hamilelik dönemi dahil sıkıkla kullanılmaktadır. Herhangi bir maddenin özellikle de hamilelik döneminde olası istenmeyen etkileri önemlidir, çünkü hızlı büyüyen fetüsün hücresel gelişimi ve hücre bölünmesi etkilenmeye açıtır. Bir bitkisel ürünün yanıt oluşturabilmesi için, bir ilacın yanıt oluşturması gibi, ürünün organizmanın bir bileşeni ile moleküler seviyede etkileşime girmesi gereklidir. Hamilelikte en sık kullanılan bitkisel preparatlar, genellikle en düşük konsantrasyonlara sahip olan ve en az miktarda bileşik içeren çaylar veya infüzyonlardır (kurutulmuş otların sıcak su özleri). Bu derlemenin amacı, hamilelikte en sık kullanılan, bitkisel çay olarak tüketilen bitkilerin olası toksik etkilerini özetleyerek kullanımında dikkatli olunması gerektiğinin önemini vurgulamaktır.

Anahtar kelimeler: Bitkisel ürün, bitkisel çay, gebelik
Received: 26 January 2020

Accepted: 10 February 2020

Online First: 28 February 2020

Corresponding Author: B. Terzioglu Bebitoglu ORCID: 0000-0003-4601-7871 İstanbul Medeniyet University, School of Medicine, Department of Medical Pharmacology, Istanbul, Turkey 


\section{INTRODUCTION}

Over the centuries, plants are being relied on by humans not only for feeding and clothing but also for medical needs. They are either produced or manufactured from roots, leaves, bark, buds, berries or seeds of the plants ${ }^{1}$.

For a drug or a herbal product to exert a response, it must at least interact with a component of the organism at molecular level. Drugs have adverse effects due to interaction with other components. This risk is even higher with plants as they contain variable mixture of compounds. Therefore, the isolation of active principles in plants and determining its amount is of great importance. With the solvent extraction technique, the compounds of plants with pharmacological activity became available. With the use of alkaloids and glycosides, the compounds with a pharmacological activity have been known and their toxic potential has been also revealed ${ }^{2}$.

Actually many pharmacological agents used today have their origins in plant-based compounds such as atropine (Atropa belladonna), ephedrine (Ephedra spp.), morphine and codeine (Papaver somniferum), cocaine (Erythroxylum coca), pilocarpine (Pilocarpus jaborandi Holmes), and quinine (Cinchona cordifolia Mutis ex Humb) ${ }^{2}$.

World Health Organization (WHO) defines herbal medicines as "herbs, herbal materials, herbal preparations and finished herbal products that contain parts of plants, other plant materials, or combinations as active ingredients." WHO also clarifies "active ingredients" as "the ingredients of herbal medicines with therapeutic activity where the active ingredients have been identified, and if adequate analytical methods are available, the medicinal preparation should be standardized to contain a defined amount of the active ingredients". If the identification of active ingredients is not possible, then whole herbal medicine can be considered as one active ingredient ${ }^{3}$.
The potential unwanted effects of anything consumed should taken into consideration. It is especially more important during pregnancy period, because the rapidly growing fetus is vulnerable to adverse effects influential at cell growth and division. In a belief of "being natural is safe", use of herbs and herbal products have become popular worldwide and used more frequently even during pregnancy $^{4-6}$.

The prevalence of herbal medicine use during pregnancy varies depending on the studied geographical location. In a large-scale study including pregnant women across 18 countries from five different regions, herbal medicine use was noted in $\mathbf{2 8 . 9 \%}$ of pregnant women ${ }^{6}$. In another study, herbal medicines were classified according to their safety classification in pregnancy. They reported that, $29.3 \%$ of the women used herbal medicines during pregnancy, and among them, $89.0 \%$ of them used 126 specific herbal medicines. And 27 of 126 herbal medicines were classified as "contraindicated" in pregnancy, which were being used by $20.0 \%, 28$ of them as "safe" in pregnancy which were being used by $47.4 \%$ of women and 60 herbal medicines were classified as "requiring caution" in pregnancy which were being used by $31.6 \% \%^{6}$. In a study conducted in Bangladesh, the use of herbal medicines during pregnancy was reported to be $70 \%{ }^{7}$. Another study from UK reported that 25 different herbal products were being used by $37 \%$ of women during early pregnancy ${ }^{8}$. One or more herbal remedies were being used by $57.8 \%$ of at least 20 week-pregnant women in Norway9.

There are several factors related with the risks of herbs affecting the safety of pregnant women and fetus; preparation of herb (its purity) and timing of use during pregnancy ${ }^{10}$. The formulations of the herbal preparation will be different. It will have different compounds in its preparation with variable concentrations affecting its efficacy and safety in pregnant women and fetus. Herbal preparations most commonly used during pregnancy 
were teas or infusions (hot-water extracts of dried herbs) that contain the least amount of compounds, and usually have the lowest concentrations. Dried extracts and capsules are other forms of preparations that are less commonly used such as ginger and Echinacea. Tinctures that are alcohol extracts of dried herbs should be avoided in pregnancy because of the high concentration of compounds and alcohol content as a carrier ${ }^{10}$.

The effects and safety of herbs will depend on the trimester they are used in ${ }^{10}$. The first trimester is the most important period as it is also for pharmaceuticals. The rapid cellular development in organogenesis can be changed by any compound. Therefore, special caution is needed while using herbal products during pregnancy. The purpose of this short update was to summarize the most commonly used herbal teas in pregnancy and their potential toxic effects to highlight the importance of being cautious.

\section{Frequently used herbal teas during pregnancy}

Herbs are frequently used as teas or infusions during pregnancy. However, there are no clinical trials and no evidence-based proof regarding their safety. They have been considered to be safe and so used for many years. Thus, their recommended consumption is to be limited to two cups per day during pregnancy ${ }^{10}$.

Commonly used herbs during pregnancy were known to be raspberry, fennel, peppermint, ginger, thyme, chamomile, sage and green tea ${ }^{10}$. Linden, peppermint-lemon, ginger have been reported to be the most commonly used herbal products in pregnancy during $1^{\text {st }}$ and 2 nd trimesters in a study conducted in Turkey ${ }^{11}$. Moreover, in a preliminary study conducted to evaluate the attitudes of primary care physicians towards herbal medicines used during pregnancy revealed that fennel, linden and cinnamon are the most commonly used and recommended herbal teas among pregnant women in İstanbul ${ }^{12}$.
The red raspberry leaf is one of the most commonly used herbal tea during pregnancy primarily due to its assumed labor stimulation effect ${ }^{13,14}$. However the need for labor stimulation or duration of labor has not been demonstrated in any study $^{15}$. Like all compounds, the pregnancy risks associated with raspberry leaf have not been well studied. A 38-year-old woman with gestational diabetes mellitus using insulin, developed hypoglycemia after consuming raspberry leaf tea at 32 weeks of gestation and she had to lower her insulin dose. The relationship of her condition with raspberry leaf tea was confirmed but the extent of effect with the amount use is unknown ${ }^{16}$. In animal studies, the hypoglycemic effects of blackberry leaves have been recorded and suggested to be related to raspberry leaves ${ }^{17,18}$. The animal and clinical studies are inadequate and unable to rule out other undesirable effects on pregnancy outcomes without any additional benefit ${ }^{19}$. It was classified in "use with caution in pregnancy" category ${ }^{6}$.

Peppermint is another plant used to relieve flatulence and emesis thanks to its antispasmodic, and breast milk enhancer effects. Also it acts as a sedative, and used for the treatment of respiratory and urinary tract infections $\mathrm{s}^{20-22}$ and morning sickness in pregnancy even though it is B2 Category ${ }^{23,24}$. Inhalation of its essential oil can be used to reduce fever, relieve nausea and vomiting, and improve digestion ${ }^{25}$. The antiemetic mechanism of essential oil of peppermint was based on its 5-HT3 receptor antagonistic effects ${ }^{26}$. Any harmful effect of peppermint tea to mother or fetus has not been shown ${ }^{6,1}$. However its excessive use is contraindicated in early pregnancy due to its emmenagogue effects ${ }^{22}$. On the other hand, in a randomized placebo controlled study, conducted on women with nausea and vomiting during first half of pregnancy, the nausea and vomiting decreasing effect of peppermint oil aromatherapy and placebo were found to be the same ${ }^{27}$. According to safety classification of herbal medicines used during pregnancy, peppermint (15.9\%) is one of 
the most frequently used herbal medicines classified as safe ${ }^{6}$.

German chamomile (Matricaria recutita) is another most commonly used herbal supplement. In a study its at least weekly usage is reported during pregnancy $(7.5 \%)^{28}$. It is used for relief of gastrointestinal irritation, insomnia, and joint irritation. However with regular use, a higher incidence of preterm labor or miscarriage has been reported ${ }^{29}$. Constricted ductus arteriosus was detected in a 34-year-old woman, at 20 weeks' gestation, who reported drinking camomile tea on a regular basis, and her condition was improved after stopping consumption of German chamomile tea. Another 32-year-old woman, at 35 weeks' gestation, presented with ductal constriction. She reported intermittent consumption of camomile tea during pregnancy $^{30}$. Ductal constriction associated with camomile tea use is similar to nonsteroidal antiinflammatory drug (NSAIDs) use which are also known to cause ductal constriction in depending on its dose, duration of its use, and gestational age. Animal studies with Camomile tea (Camellia sinensis) root extract have demonstrated its antiinflammatory activity ${ }^{31}$. Chamomile was shown to have more than 120 chemical secondary metabolites, including phenolic compounds like flavonoids, sesquiterpenes and coumarins ${ }^{31,32}$. Due to its content of coumarins, there may be risk of an additive effect when taken with warfarin ${ }^{20}$. It has affinity with estrogenic receptors as coumarins, flavonoids and miscellaneous phenolic compounds. Several of them were detected to have, theoretically, more affinity than estradiol to estrogenic receptors ${ }^{33}$. In a retrospective study where risks of herbal products on pregnancy and neonatal outcomes were investigated, the regular chamomile consumption during third trimester was found to be associated with higher risk of pre-term delivery and lower birth weight ${ }^{34}$. Eventually, use of chamomile was considered to be unsafe during pregnancy with adverse perinatal outcomes.
Ginger is usually used for nausea in pregnant women especially in the first trimester ${ }^{35}$. A systematic review of twenty four trials revealed that dose of 35-500 mg ginger and vitamin B6 have been shown to have identical effects against nausea and vomiting of pregnancy ${ }^{36}$. For pregnant women with hyperemesis gravidarum, 1 gram per day ( $250 \mathrm{mg} 4$ times a day) for four days was used effectively and adverse effects were not reported. All infants were normal. Only one spontaneous abortion occurred; but a causal relationship with use of ginger was not determined ${ }^{37}$. The major part of the antiemetic activity may be due to its ingredient 6-gingerol that acts directly in the gastrointestinal tract $^{38}$. In hyperemesis, ginger may act by stimulating the motility of the gastrointestinal tract and its absorbent property may reduce stimuli to the chemoreceptor zone. It may block the gastrointestinal reactions and the subsequent nausea feedback ${ }^{39}$. The ginger also acts on 5-HT3 receptors in the ileum with serotonergic effect and anti-hydroxytryptamine activity ${ }^{40,41}$. There are several randomized control studies showing the relieving effect of ginger in nausea and vomiting of pregnancy and it is used in different doses and durations. Ginger used in first trimester has been associated with some non-dose-dependent adverse drug reactions, such as dry mouth or worsening of nausea and dehydration ${ }^{42,43}$, and during second and third trimesters, it has been associated with bleeding or spotting ${ }^{44}$. Ginger use throughout pregnancy was reported to be associated with a significant prematurity and decrease in neonatal head circumference at birth ${ }^{34}$. Its interaction with drugs that can be used during pregnancy such as insulin, metformin, and nifedipine has been reported ${ }^{45}$. Risk of vaginal bleeding was reported to be associated with ginger use in pregnant women due to its possible inhibiting thromboxane synthetase activity ${ }^{46,47}$. Interaction of ginger with fetal testosterone metabolism has been also shown ${ }^{48,49}$. Ginger's anti-inflammatory and analgesic effects have been demonstrated and its use in dysmenorrhea has been suggested to be due to its inhibition of cyclooxygenase en- 
$z^{2 y m e}{ }^{50}$. As there are concerns regarding its safety for women, if ginger is to be used during pregnancy, it should be in limited amounts ${ }^{10}$. The recommended dose is $1,000 \mathrm{mg}$ per day for nausea and vomiting of pregnancy, not to exceed $4 \mathrm{~g}$, due to its uterine stimulating effects ${ }^{51}$.

Fennel (Foeniculum vulgare), another commonly consumed plant is available in teas. Its dried ripe fruit or seeds have shown to exert estrogenic effects that may cause increase in menstruation and libido ${ }^{52}$. Its main constituents; anethole, dianethole and photoanethole are considered to be responsible for these estrogenic effects ${ }^{53,54}$. Its favorable effects in hormonal disorders in women have been reported including alleviation of the symptoms of the menopause, improvement of fertility and enhancing lactation. The effects of oral fennel oil use in dysmenorrhea, premenstrual syndrome, amenorrhea and polycystic ovary syndrome have been also clinically demonstrated ${ }^{55}$. Its anti-spasmodic effects were studied in rats and fennel essential oil was shown to reduce the frequency of contractions induced by PGE2 in isolated rat uterus ${ }^{56}$.

The effect of fennel oil on in vitro reduction in limb bud differentiation of rat embryo demonstrated that it has toxic effects on fetal cells, without evidence of teratogenicity ${ }^{57}$. Although it is used for years, there are still concerns regarding its potential adverse effect. Also fennel extracts were known to have human liver cytochrome P450 enzyme inhibitory activity causing potential interactions with other drugs ${ }^{58}$. It is also commonly used during lactation period for its curative effects on infantile colic ${ }^{55}$. As reported in the literature 12-month-old girl given two to three teaspoons of fennel tea by her mother every day for the last 6 months developed isolated premature thelarche ${ }^{59}$. Two women who consumed herbal tea containing fennel and cumin to induce lactation during postpartum period presented with hepatotoxicity ${ }^{60,2}$.

\section{CONCLUSION}

Most commonly used herbs are safe when consumed in moderate amounts. Consumption of large quantities are not recommended due to their interference with various metabolic processes. Current data suggest that herbal medicinal products such as raspberry leaf, peppermint, chamomile, fennel and ginger used during pregnancy may be associated with adverse maternal and perinatal outcomes or toxicity from contaminants.

\section{REFERENCES}

1. Salim AA, Chin YW, Kinghorn AD. Drug Discovery from Plants. In: Ramawat KG, Mérillon JM, editors. Bioactive Molecules and Medicinal Plants. Berlin, Heidelberg: Springer, 2008. p. 1-24. [CrossRef]

2. Sneader W. Drug Discovery: A History. John Wiley \& Sons Ltd; 2005. [CrossRef]

3. World Health Organization. Programme on Traditional Medicine. General guidelines for methodologies on research and evaluation of traditional medicine. (2000). $1^{\text {st }}$ ed. Geneva. WHO/EDM/TRM/2000.1

Available from: https://apps.who.int/medicinedocs/pdf/ whozip42e/whozip42e.pdf.

4. Fakeye TO, Adisa R, Musa IE. Attitude and use of herbal medicines among pregnant women in Nigeria. BMC Complement Altern Med. 2009;9:53. [CrossRef]

5. Hall HG, Griffiths DL, McKenna LG. The use of complementary and alternative medicine by pregnant women: A literature review. Midwifery. 2011;27:817-24. [CrossRef]

6. Kennedy DA, Lupattelli A, Koren G, Nordeng H. Safety classification of herbal medicines used in pregnancy in a multinational study. BMC Complement Altern Med. 2016;16:102. [CrossRef]

7. Ahmed M, Hwang JH, Hasan MA, Han D. Herbal medicine use by pregnant women in Bangladesh: a cross-sectional study. BMC Complement Altern Med. 2018;18:333-33. [CrossRef]

8. Pallivalappila AR, Stewart D, Shetty A, Pande B, Singh R, Mclay JS. Complementary and alternative medicine use during early pregnancy. Eur J Obstet Gynecol Reprod Biol. 2014;181:251-5. [CrossRef]

9. Holst L, Wright D, Haavik S, Nordeng H. Safety and efficacy of herbal remedies in obstetrics-review and clinical implications. Midwifery. 2011;27:80-6. [CrossRef]

10. Hess HM, Miller RK. Herbs during pregnancy. Schaefer C, Peters PWJ. Miller RK, editors. Drugs During Pregnancy and Lactation Treatment Options and Risk Assessment. 3rd ed. Academic Press is an imprint of Elsevier; 2014. p. 511-25. [CrossRef]

11. Kıssal A, Çevik Güner Ü, Batkın Ertürk D. Use of herbal product among pregnant women in Turkey. Complement Ther Med. 2017;30:54-60. [CrossRef]

12. Terzioğlu Bebitoğlu B, Acet NG, Oğuz E. Prevalance, knowledge and attitudes of primary care physicians to- 
ward herbal medication use in pregnancy. $5^{\text {th }}$ International Eurasian Congress on 'Natural Nutrition, Healthy Life \& Sport'; 2019; Ankara. Malatya Turgut Ozal University Scientific Publication Series. p. 2619-20.

Available from: https://www.natural2019.com/doc/natural2019proceedingsbookv1.pdf

13. Michele Simpson MP, Jennifer Greenwood, Kenneth Wade. Raspberry leaf in pregnancy: its safety and efficacy in labor. J Midwifery Womens Health. 2001;46:51-9. [CrossRef]

14. McFarlin BL, Gibson MH, O’Rear J, Harman P. A national survey of herbal preparation use by nurse-midwives for labor stimulation. Review of the literature and recommendations for practice. J Nurse Midwifery. 1999;44:205-16. [CrossRef]

15. Parsons $M$, Simpson $M$, Ponton T. Raspberry leaf and its effect on labour: safety and efficacy. Aust Coll Midwives Inc J. 1999;12:20-5. [CrossRef]

16. Cheang KI, Nguyen TT, Karjane NW, Salley KE. Raspberry Leaf and Hypoglycemia in Gestational Diabetes Mellitus. Obstet Gynecol. 2016;128:1421-4. [CrossRef]

17. Jouad H, Maghrani M, Eddouks M. Hypoglycaemic effect of Rubus fructicosis L. and Globularia alypum L. in normal and streptozotocin-induced diabetic rats. J Ethnopharmacol. 2002;81:351-6. [CrossRef]

18. Bispo K, Amusquivar E, Garcia-Seco D, Ramos-Solano B, Gutierrez-Mañero J, Herrera E. Supplementing diet with blackberry extract causes a catabolic response with increments in insulin sensitivity in rats. Plant Foods Hum Nutr. 2015;70:170-5. [CrossRef]

19. Holst L, Haavik S, Nordeng H. Raspberry leaf--should it be recommended to pregnant women? Complement Ther Clin Pract. 2009;15:204-8. [CrossRef]

20. Thomson F. PDR for herbal medicines. $4^{\text {th }}$ ed. Montvale, New Jersey: Thomson; 2007.

21. World Health Organization. WHO monographs on medicinal plants commonly used in the newly independent states (NIS). $1^{\text {st }}$. Geneva; 2010.

Available from: https://apps.who.int/medicinedocs/documents/s17534en/s17534en.pdf

22. Fleming T. Physicians' Desk Reference for herbal medicines. $4^{\text {th }}$ ed. United States of America: Thomson health care Inc; 2000: p. 121, 414, 522, 649.

23. Lawless J. The encyclopedia of essential oils: the complete guide to the use of aromatic oils in aromatherapy, herbalism, health and well being. $1^{\text {st }}$ ed. San Francisco: Red Wheel Weiser; 2013. p. 224.

24. Mills SY, Bone K, Mills S, Bone K. The essential guide to herbal safety. $1^{\text {st }}$ ed. United States of America: Elsevier Churchill Livingstone; 2005. p. 704.

25. Fundukian LJ. The gale encyclopedia of alternative medicine. $4^{\text {th }}$ ed. United States of America: Thomson Gale; 2014: p. 2848.

26. Heimes K, Hauk F, Verspohl EJ. Mode of action of peppermint oil and (-)-menthol with respect to 5-HT3 receptor subtypes: binding studies, cation uptake by receptor channels and contraction of isolated rat ileum. Phytother Res. 2011;25:702-8. [CrossRef]

27. Joulaeerad N, Ozgoli G, Hajimehdipoor H, Ghasemi E, Salehimoghaddam F. Effect of aromatherapy with peppermint oil on the severity of nausea and vomiting in pregnancy: a single-blind, randomized, placebo-controlled trial. J Reprod Infertil. 2018;19:32-8.

28. Gibson PS, Powrie R, Star J. Herbal and alternative medi- cine use during pregnancy: a cross-sectional survey. Obstet Gynecol. 2001;97(Suppl 1):44-5. [CrossRef]

29. Cuzzolin L, Francini-Pesenti F, Verlato G, Joppi M, Baldelli P, Benoni G. Use of herbal products among 392 Italian pregnant women: focus on pregnancy outcome. Pharmacoepidemiol Drug Saf. 2010;19:1151-8. [CrossRef]

30. Sridharan S, Archer N, Manning N. Premature constriction of the fetal ductus arteriosus following the maternal consumption of camomile herbal tea. Ultrasound Obstet Gynecol. 2009;34:358-9. [CrossRef]

31. Chattopadhyay P, Besra SE, Gomes A, et al. Anti-inflammatory activity of tea (Camellia sinensis) root extract. Life Sci. 2004;74:1839-49. [CrossRef]

32. Miguel FG, Cavalheiro AH, Spinola NF, et al. Validation of a RP-HPLC-DAD method for chamomile (matricaria recutita) preparations and assessment of the marker, apigenin7-glucoside, safety and anti-Inflammatory effect. Evid Based Complement Alternat Med. 2015;2015:828437. [CrossRef]

33. Powers CN, Setzer WN. A molecular docking study of phytochemical estrogen mimics from dietary herbal supplements. In Silico Pharmacol. 2015;3:4. [CrossRef]

34. Trabace L, Tucci P, Ciuffreda L, et al. "Natural" relief of pregnancy-related symptoms and neonatal outcomes: above all do no harm. J Ethnopharmacol. 2015;174:396402. [CrossRef]

35. Broussard CS, Louik C, Honein MA, Mitchell AA. Herbal use before and during pregnancy. Am J Obstet Gynecol. 2010;202:443.e1-6. [CrossRef]

36. Khorasani F, Aryan H, Sobhi A, et al. A systematic review of the efficacy of alternative medicine in the treatment of nausea and vomiting of pregnancy. J Obstet Gynaecol. 2020;40:10-9. [CrossRef]

37. Fischer-Rasmussen W, Kjaer SK, Dahl C, Asping U. Ginger treatment of hyperemesis gravidarum. Eur J Obstet Gynecol Reprod Biol 1991;38:19-24. [CrossRef]

38. Mills E, Dugoua JJ, Perri D, Koren G. Herbal Medicines in Pregnancy and Lactation. $1^{\text {st }}$ ed. London: CRC Press; 2006. [CrossRef]

39. Mowrey DB, Clayson DE. Motion sickness, ginger, and psychophysics. Lancet. 1982;1(8273):655-7. [CrossRef]

40. Yamahara J, Rong HQ, Iwamoto M, Kobayashi G, Matsuda $\mathrm{H}$, Fujimura $\mathrm{H}$. Active components of ginger exhibiting anti-serotonergic action. Phytother Res. 1989;3:70-1. [CrossRef]

41. Huang $Q R$, Iwamoto $M$, Aoki $S$, et al. Anti-5-hydroxytryptamine3 effect of galanolactone, diterpenoid isolated from ginger. Chem Pharm Bull (Tokyo). 1991;39:397-9. [CrossRef]

42. Willetts KE, Ekangaki A, Eden JA. Effect of a ginger extract on pregnancy-induced nausea: a randomised controlled trial. Aust N Z J Obstet Gynaecol. 2003;43:13944. [CrossRef]

43. Firouzbakht $M$, Nikpour $M$, Jamali B, Omidvar S. Comparison of ginger with vitamin B6 in relieving nausea and vomiting during pregnancy. Ayu. 2014;35:289-93. [CrossRef]

44. Heitmann K, Nordeng H, Holst L. Safety of ginger use in pregnancy: results from a large population-based cohort study. Eur J Clin Pharmacol. 2013;69:269-77. [CrossRef]

45. McLay JS, Izzati N, Pallivalapila AR, et al. Pregnancy, prescription medicines and the potential risk of herb-drug interactions: a cross-sectional survey. BMC Complement Altern Med. 2017;17:543. [CrossRef] 
46. Backon J. Ginger in preventing nausea and vomiting of pregnancy; a caveat due to its thromboxane synthetase activity and effect on testosterone binding. Eur J Obstet Gynecol Reprod Biol. 1991;42:163-4. [CrossRef]

47. Marx W, McKavanagh D, McCarthy AL, et al. The Effect of Ginger (Zingiber officinale) on Platelet Aggregation: A Systematic Literature Review. PLoS One 2015;10:e0141119. [CrossRef]

48. Sondergaard K. [Ginger, pregnancy nausea and possible fetal injuries (testosterone effect)]. Ugeskr Laeger. 2008; 170:359; author reply 59.

49. Volqvartz T, Vestergaard AL, Aagaard SK, et al. Use of alternative medicine, ginger and licorice among Danish pregnant women - a prospective cohort study. BMC Complement Altern Med. 2019;19:5. [CrossRef]

50. Rahnama P, Montazeri A, Huseini HF, Kianbakht S, Naseri $M$. Effect of Zingiber officinale R. rhizomes (ginger) on pain relief in primary dysmenorrhea: a placebo randomized trial. BMC Complement Altern Med. 2012;12:92. [CrossRef]

51. Borrelli F, Capasso R, Aviello G, Pittler MH, Izzo AA. Effectiveness and safety of ginger in the treatment of pregnancy-induced nausea and vomiting. Obstet Gynecol. 2005;105:849-56. [CrossRef]

52. Albert-Puleo M. Fennel and anise as estrogenic agents. J Ethnopharmacol. 1980;2:337-44. [CrossRef]

53. Howes MJ, Houghton PJ, Barlow DJ, Pocock VJ, Mil- ligan SR. Assessment of estrogenic activity in some common essential oil constituents. J Pharm Pharmacol. 2002;54:1521-8. [CrossRef]

54. Dhar SK. Anti-fertility activity and hormonal profile of trans-anethole in rats. Indian J Physiol Pharmacol. 1995;39:63-7.

55. Mahboubi M. Foeniculum vulgare as Valuable Plant in Management of Women's Health. Journal of menopausal medicine 2019;25:1-14. [CrossRef]

56. Ostad SN, Soodi M, Shariffzadeh M, Khorshidi N, Marzban $\mathrm{H}$. The effect of fennel essential oil on uterine contraction as a model for dysmenorrhea, pharmacology and toxicology study. J Ethnopharmacol. 2001;76:299-304. [CrossRef]

57. Ostad SN, Khakinegad B, Sabzevari O. Evaluation of the teratogenicity of fennel essential oil (FEO) on the rat embryo limb buds culture. Toxicol In Vitro. 2004;18:623-7. [CrossRef]

58. Smeriglio A, Tomaino A, Trombetta D. Herbal products in pregnancy: experimental studies and clinical reports. Phytother Res. 2014;28:1107-16. [CrossRef]

59. Okdemir D, Hatipoglu N, Kurtoglu S, Akin L, Kendirci M. Premature thelarche related to fennel tea consumption? J Pediatr Endocrinol Metab. 2014;27:175-9. [CrossRef]

60. Zengin S OM, Kamalak M, AI B, Yildirim C, Büyükaslan H. Acute hepatitis associated with the use of herbal tea (Fennel and cumin). J Clin Anal Med. 2015;6:781-3. [CrossRef] 